\title{
NOS LIMITES DA VIDA, DA MORTE E DA LINGUAGEM: O ACASO NO CINEMA DE WOODY ALLEN*
}

\author{
Fernanda Valim Côrtes Miguel \\ "O que ainda é um jogo e o que não é mais? \\ Vocêpode traçar os limites?" \\ (Wittgenstein, IF-68) \\ "Eu não lembrava um motivo para viver e, \\ quando lembrei, não era convincente" \\ (Abe Lucas, protagonista de Homem Irracional) \\ "às vezes, o melhor é nem ter nascido" \\ (Chris, protagonista de Match Point)
}

\begin{abstract}
Resumo:
Qual seria o papel do acaso em nossa vida? Até que ponto seus movimentos aleatórios e imprevisíveis poderiam determiná-la? Sorte, destino e acaso são temas e argumentos recorrentemente elaborados nas narrativas cinematográficas de Woody Allen, sempre relacionados à uma reflexão sobre o sentido da vida, numa oscilação entre o trágico e o cômico. O acaso nos filmes do diretor se apresenta como problemática existencial, suscitando reflexões mais amplas sobre o planejamento e a intencionalidade das ações dos personagens, seus dilemas éticos, estéticos e morais e eventuais consequências, que poderiam desencadear crises de consciência e dramas psicológicos. O capítulo realiza um estudo da filmografia de Woody Allen a partir de uma investigação crítico-terapêutica, percorrendo a presença fundamental do acaso que atravessa suas produções. Para isso, partimos do filme Match Point (2005) em diálogo com os aforismos de Wittgenstein sobre o jogo de tênis e da compreensão do filósofo sobre a imprevisibilidade dos jogos de linguagem. Em seguida, buscamos percorrer o tema e suas possíveis semelhanças de família em outros filmes do diretor, como Crimes e pecados (1989), Hannah e Suas Irmãs (1986), O Homem Irracional (2015), Scoop - O Grande Furo (2006), Tudo pode dar certo (2009), em diálogo com o romance Crime e Castigo (1866), de Fiódor Dostoiévski e reflexões sobre a tragédia e a linguagem. A perspectiva terapêutica de Wittgenstein, ao se afastar da tentativa de estabelecer um sentido lógico e causal para os fatos e acontecimentos de nossas vidas acaba por reconhecer que as regras de um jogo nunca são prescritivas e que a tragédia da linguagem se daria a partir da constatação de sua radical incapacidade de descrever o que realmente importa, o mistério.
\end{abstract}

Palavras-chave: Acaso; Match Point; Woody Allen; Dostoiévski; Wittgenstein.

\footnotetext{
* DOI - 10.29388/978-65-86678-51-2-0-f.629-654

1 A frase do protagonista de Match Point (ALLEN, 2005) se refere à seguinte passagem de Édipo em Colono, expressa pelo coro: "Não ser nascido prevalece a todo argumento. / Mas, posto que se vem à luz, / tornar célere para lá, de onde / se veio, é o melhor a fazer" (SÓFOCLES, 1990, versos 1224-1227).
} 
Diante da diversidade de diretores, diretoras e roteiristas de cinema no contexto mais recente e de produções igualmente marcantes, a filmografia de Woody Allen segue consolidando uma estética notoriamente autoral, na contramão dos interesses deliberados de Hollywood em fazer conquistar milhões de espectadores através do apelo à violência brutalizada e da oferta de experiências de choques puramente físicos. O diretor, que é também músico, roteirista e ator, dirigiu seus primeiros filmes na década de 1960. Seu humor peculiar e a inteligência de suas comédias dramáticas priorizam o gosto pelos anti-heróis, pela ficção permeada de elementos pessoais, pela crítica à sociedade - incluindo a estadunidense - e pelo trabalho rigoroso com a linguagem estética, o roteiro de seus filmes, a construção de seus personagens, pensamentos e sentimentos. Allen parece dar continuidade à uma tradição de artistas que acreditam que fazer filmes significa necessariamente refletir sobre o cinema e seu papel transformador do mundo.

Como pontuou certa vez François Truffaut, em "Woody Allen, um pessimista alegre", Noivo neurótico, noiva nervosa (ALLEN, 1977) seria um marco notório de suas produções, em que o diretor teria conseguido se desvincular do restritivo rótulo de "autor de filmes cômicos":

Entre $O$ dorminhoco, que era estritamente paródico, e Noivo neurótico, que pertence à comédia dramática, Allen fez como ator um papel totalmente sério em Testa-de-ferro por acaso, como para habituar progressivamente o público à mudança de sua imagem [...] . Os progressos do diretor, entre Um assaltante bem trapalhão (1969), que era engraçado mais informe, e Noivo neurótico, bem enquadrado, rigoroso, são espantosos, como será daqui para a frente a atenção dirigida a seus parceiros [...] (TRUFFAUT, 2005, p. 64).

Truffaut também relembra a admiração de Allen por Bergman e Fellini, assim como Hitchcock, frequentemente e habilmente citados em seus filmes, e comenta sobre um tema caro ao diretor: "o amor, claro! Por que os amores acabam como começaram, não é este o melhor tema para um filme e também para mil filmes, já que cada homem viveu sua própria história e cada história vale a pena ser filmada - contanto que seja com intuição, astúcia e sensibilidade?" (TRUFFAUT, 2005, p. 63). Assim como em Noivo neurótico, noiva nervosa, muitos outros filmes do diretor tematizam o amor nova-iorquino em tom antihollywoodiano. E justamente o tema do amor atravessa os filmes do diretor em um curioso jogo que transita entre a intencionalidade da relação afetiva, a insatisfação com a vida e com o momento presente e a imprevisibilidade da paixão, como em Noivo neurótico, noiva nervosa, em que um o humorista judeu e divorciado, que faz análise há anos, se apaixona por uma cantora complicada em início de carreira; ou como em Meia-Noite em Paris (ALLEN, 2011), em que um jovem escritor, de férias com sua noiva, sai sozinho para explorar a cidade e é misteriosamente conduzido a uma viagem ao passado, conhecendo grandes personalidades da literatura e se desencantando com a vida que levava. Em Manhattan (ALLEN, 1979), acompanhamos as frustrações amorosas de um roteirista de TV em crise de meia-idade, depois que sua terceira esposa o abandona por uma mulher; e em Café Society (ALLEN, 2016), um jovem judeu, aspirante a escritor, que deseja ingressar na indústria cinematográfica, acaba se apaixonando pela secretária se seu tio, um produtor que faz parte da elite de Hollywood. O filme explora a ingenuidade romântica do artista e a irracionalidade da paixão em contraponto ao perverso jogo de interesses de classe, os bastidores da indústria cinematográfica e o desejo de ascensão social, cujos efeitos caminham para aspectos bastante 
melancólicos. De um lado, a insegurança e o prazer do amor de um jovem sem recursos, de outro o dever e a segurança financeira promovida pelo namorado bem-sucedido. A escolha de Vonnie é pela segunda opção, apontando para o fato de que a dor da escolha sempre implica em renúncia. Como afirma o jovem artista: "A vida é uma comédia escrita por um sádico autor de comédia" (ALLEN, 2016).

A questão da imprevisibilidade do desejo e da paixão é tratada de maneiras diferentes em grande parte desses filmes, tanto mais instigantes quando aproximadas à questão dos interesses, da arte e do mistério: Woody Allen explora com maestria os limites da racionalidade e da casualidade, abusando das metáforas dos jogos - tarôs, xadrez, tênis, cartas, roleta russa -, das técnicas da psicanálise, da hipnose, da magia e da astrologia, colocando o universo da sensibilidade artística em contraponto ao normatizado e repulsivo mundo burguês, ironizando com humor refinado personagens que construíram fama e prestígio através principalmente da capacidade de sua intelectualidade. É o caso de Stanley, em Escorpião de Jade (ALLEN, 2001), um mágico que dedica a sua vida a revelar espiritualistas fraudulentos e acaba se aproximando da jovem Sophie, por quem se apaixona, tentando descobrir se ela é mesmo uma médium, como todos ao redor acreditam. No filme, o próprio diretor faz o papel de um investigador de seguros da década de 1940 que se orgulha da própria capacidade de capturar qualquer trapaceiro através de seu meticuloso intelecto. No entanto, suas certezas profissionais são colocadas em xeque quando ele é chamado a desvendar uma série de crimes conduzidos por um ladrão que utilizava o medalhão Escorpião de Jade para conduzir suas vítimas a cometer os roubos sob estado hipnótico.

Já na comédia Tudo pode dar certo (ALLEN, 2009), Boris é um intelectual aposentado e hipocondríaco, quase indicado para o prêmio Nobel de física, que se diverte dando aulas de xadrez para as crianças e proclamando o fracasso da espécie humana. Com suas certezas já inabaladas, ele não tem mais a ilusão nem o desejo de se curar, até que a primeira delas começa a ruir através de um encontro casual com a bela e jovem Melody, de Mississipi, que reflete muito de sua própria condição:

Inacreditável. O fator do acaso na vida é imprevisível. Você entrou no mundo como um evento aleatório vindo de algum lugar do Mississipi. Eu surgi através da conjunção entre Sam e Yetta Yellnikoff, no Bronx décadas antes. E através de uma astronômica combinação de circunstancias nossos caminhos cruzam. Dois fugitivos no enorme, escuro, universo violento e indiferente (ALLEN, 2009).

A partir deste encontro improvável outros mais acontecem e a trama do enredo brinca com humor com os milagres da vida a partir da intervenção copiosa do acaso, como se um otimismo esperançoso pudesse brotar até mesmo de um pessimista irredutível. Boris conversa diretamente com seu espectador, através do recurso de olhar conscientemente para a lente da câmera principal. Nesses diálogos, ele reflete sobre a tentativa de dar um sentido para sua vida:

De toda forma, o que tudo significa? Nada, zero, necas. Tudo dá em nada e, ainda assim, não faltam idiotas tagarelando [...]. Nem tudo depende da sua engenhosidade humana. Uma parte de sua existência, maior do que você gostaria de admitir, é pura sorte [...]. E mesmo com tudo isso, ainda chega o dia em que te colocam em um caixão. E aí é a vez da próxima geração de idiotas que também vão te falar tudo sobre a vida, e definir para você o que é apropriado. Meu pai cometeu suicídio, por que os jornais matinais o 
deixaram deprimido. E dá para culpá-lo? Com o horror, a corrupção, ignorância, pobreza, genocídio, AIDS, e aquecimento global, e terrorismo, e os idiotas dos "valores da família" e os babacas do armamento! "O Horror", disse Kurtz no final de The Heart of Darkness, “O horror!” [...] (ALLEN, 2009).

A ironia final do filme é curiosa, pois Boris acaba se relacionando amorosamente com uma vidente e os questionamentos, sobre a vida possuir ou não um sentido, são tensionados com leveza e humor.

Os filmes de Woody Allen marcam idiossincrasias conscientes e percorrem temáticas que retornam permanentemente em suas obras - como espécie de croquis esboçados até a entrega do desenho final -, elas vão dos conflitos amorosos, morais e filosóficos, às problemáticas existenciais, traições e dificuldades nas relações cotidianas, passando por representações da cultura judaica, por reflexões sobre o ateísmo, sobre as crenças e a temática do destino e da predestinação em contraponto à ação do acaso. Interessa-nos aqui este argumento recorrente em parte de suas narrativas, o papel desempenhado pela sorte, pelo destino e pela casualidade e as implicações do planejamento e da intencionalidade das ações dos personagens, seus dilemas éticos e eventuais consequências, que poderiam desencadear crises de consciência e dramas psicológicos.

Próximo ao tom de comédias como Sonhos Eróticos de uma Noite de Verão (1983), Édipo Arrasado (1989) e O Escorpião de Jade (2001), Scoop - o grande furo (ALLEN, 2006) também projeta os grandes temas da magia e do universo místico como planos centrais da narrativa, com a diferença que, desta vez, o tom de suspense detetivesco é incluído na trama. Uma aspirante à jornalista, Sondra Pransky, é convidada aleatoriamente na plateia para participar de um show de mágica. Ao entrar dentro da caixa do truque ela recebe a visita de um espectro, justamente o espírito materalizado de Joe Strombel, um renomado jornalista recém-falecido e que retorna de sua passagem para o mundo dos mortos para revelar uma informação valiosa, que ele descobriu na barca da morte através de uma conversa com outra morta assassinada por envenenamento: o nome do suposto "assassino do tarô", um serial killer procurado pela polícia, indicando que ele seria uma importante e rica personalidade da cidade. A bela estudante pede ajuda ao mágico Splendini - interpretado pelo próprio Woody Allen - para investigar o caso.

Interessante no filme é que a imprensa é representada como o "O olho de Deus", uma espécie de justiça falha, mas necessária para desvendar o crime. No entanto, é o evento sobrenatural que desencadeia toda a investigação e o sucesso do furo de reportagem, que acaba sendo pura obra do acaso. Próximo à cena final, o mágico morre em um acidente de carro em episódio divertidíssimo, já que não estava acostumado a dirigir do lado contrário, como acontece em Londres. O espectro do personagem aparece então na travessia do barco da morte, fazendo seus truques de mágica aos demais passageiros, em uma alegoria dantesca que remete tanto ao filme A última noite de Boris Grushenko (ALLEN, 1975) - em que o encontro com a morte aparece pela primeira vez na filmografia de Allen -, quando à cena antológica de Ingmar Bergman em O Sétimo Selo (1957). 
Figura 01 - Cena final do filme Scoop - o grande furo (2006), de Woody Allen

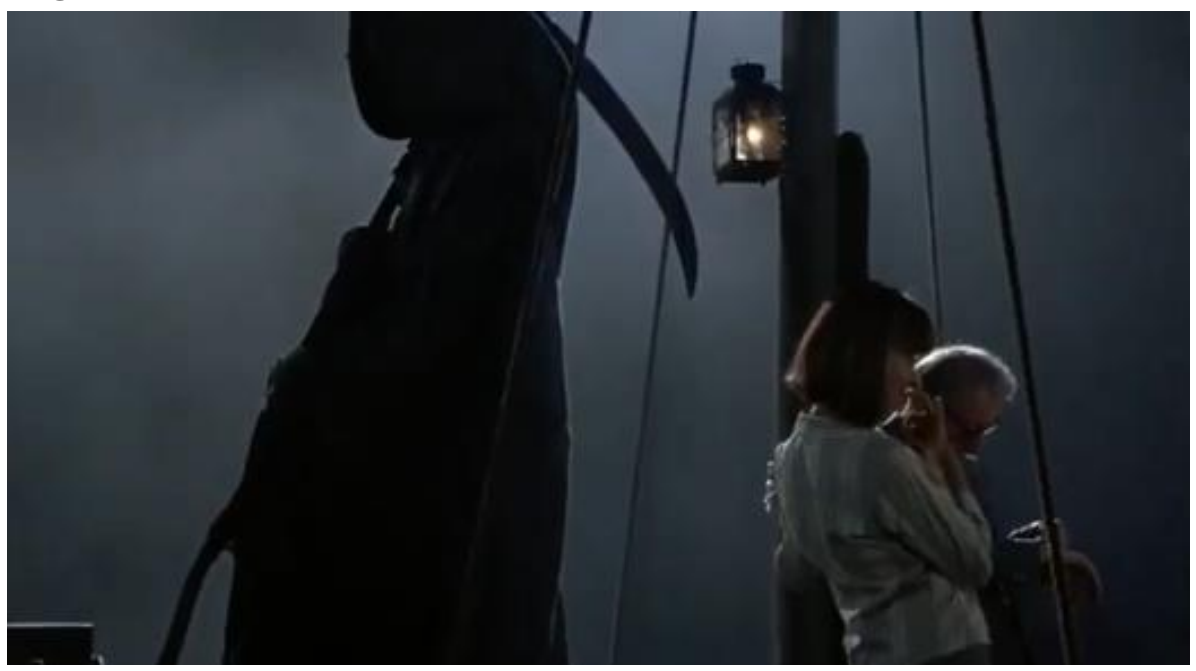

Fonte: (ALLEN, 2006)

Figura 02- Cena final do filme A última noite de Boris Grushenko, de Woody Allen.

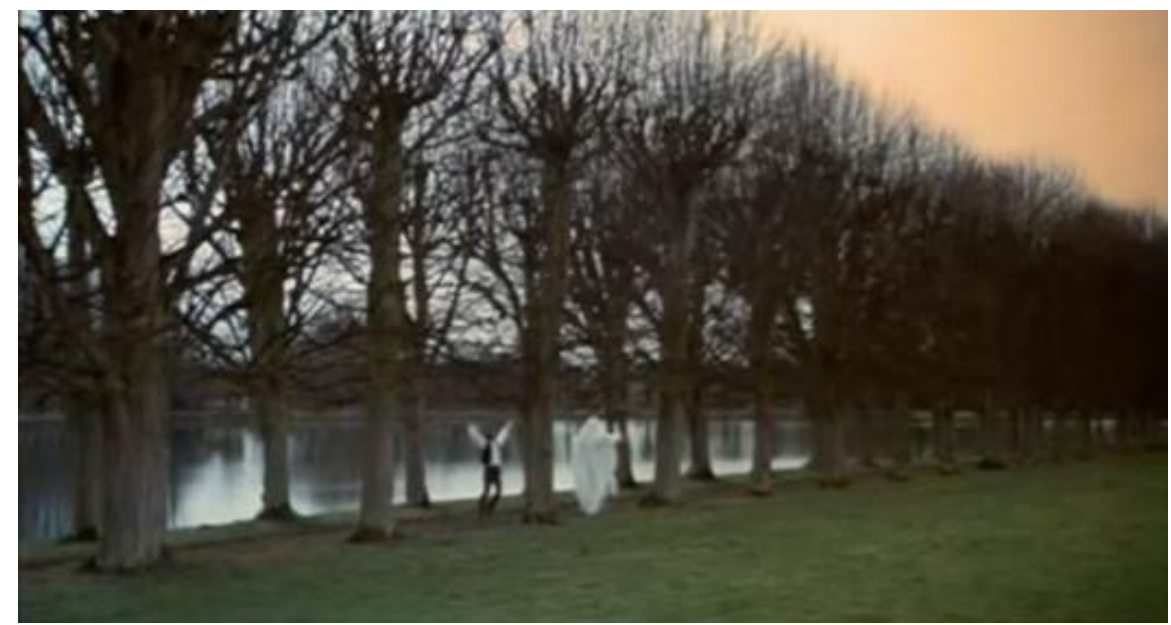

Fonte: (ALLEN, 1975).

Figura 03 - Cena do filme O Sétimo Selo (1957), de Bergman.

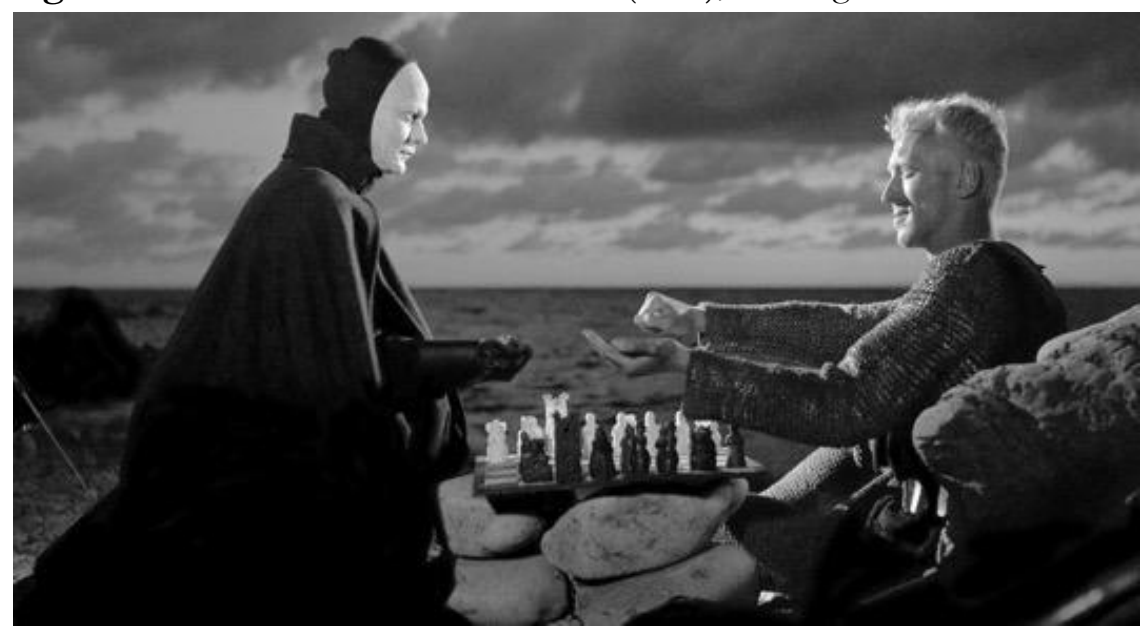

Fonte: (BERGMAN, 1957). 
Em A última noite de Boris Grushenko (ALLEN, 1975), a reflexão sobre o amor, sobre o pacifismo, sobre o ser humano e sua finitude aparecem como argumentos centrais, e a semelhança de família com $O$ Sétimo Selo surge a partir da figura da Morte enquanto personagem alegórica que pode ser desafiada, mas que acaba sempre vencedora: como no filme de Bergman, em que o jogo de xadrez se desenrola ao longo da trama, aqui também, no jogo de cena em que Boris dança com a morte, a resposta acerca de qual será o jogador que dará o xeque-mate é certa e infalível, ressalvada a diferença em relação ao humor e à comicidade que atravessa o filme Allen. No epílogo do filme, o personagem pontua sua despedida em tom igualmente humorístico:

Trigo. Estou morto, e elas conversam sobre trigo! A questão é: aprendi alguma coisa sobre a vida? Apenas que... os seres humanos são divididos em mente e corpo. A mente abrange todas as aspirações mais nobres, como poesia, filosofia, mas o corpo tem toda a diversão. O importante, penso eu, é não ser amargo. Sabe, se acontecer de Deus existir, não acho que Ele seja mau. Acho que o pior que se pode dizer dele é que, basicamente, é medíocre. Afinal, há coisas piores na vida do que a morte. Se você já passou uma noite com um vendedor de seguros, você sabe exatamente o que quero dizer. O ponto-chave aqui é não pensar na morte como um fim, pense nela mais como um jeito bem eficaz de cortar despesas. Quanto ao amor... Bem, o que se pode dizer? [...] Tchau (ALLEN, 1975).

A partir de uma investigação crítico-terapêutica, é nosso propósito, neste capítulo, identificar diferentes manifestações do acaso em alguns filmes do diretor, descrevendo possíveis semelhanças de família entre elas, bem como entre elas e outras obras fílmicas e artísticas. Para isso, partimos de Match Point (ALLEN, 2005) em diálogo com alguns aforismos de Wittgenstein sobre o jogo de tênis e da compreensão do filósofo sobre a imprevisibilidade dos jogos de linguagem. Entre a moralidade e a imoralidade, entre a causa e seu suposto efeito, entre a racionalidade e o mistério, entre o premeditado e o inesperado, o ocaso e a sorte seriam operacionalizadores fundamentais da vida humana, e com seus lances aleatórios e imprevisíveis, acabariam por determiná-la, de alguma forma.

Uma investigação desta natureza - crítica e terapêutica - pretende aproximar a abordagem filosófica de Ludwig Wittgenstein, especialmente aquela realizada em suas Investigações Filosóficas (1979), das discussões da Teoria Crítica (HORKHEIMER, 2002), em especial das ideias de Theodor Adorno $(1985,1993,1975)$ e do diálogo que ambos os filósofos estabeleceram com Sigmund Freud, no contexto da Viena do final do século XIX, onde surgiu a psicanálise como forma de se lidar com as neuroses, com a dor, com os eventos traumáticos da Primeira Guerra Mundial como tentativa de se explicar e de se lidar com o sofrimento humano. Freud (2010) postula uma ruptura com a tradição da lógica e do sujeito cartesiano, com o pensamento racional e consciente, admitindo a existência da dimensão de um "misterioso inconsciente", que agiria à revelia de nossas ações ordinárias e que poderia ser Acesso através da interpretação dos sonhos, momento de realização dos desejos e do relaxamento da censura. Os sonhos seriam provocados pela força de um desejo inconsciente e reprimido que conseguiu se fazer representar em alguns resíduos diurnos, mas seria possível admitir irrupções do reprimido também na vida desperta: “[...] na vida psíquica, nada do que uma vez se formou pode perecer" (FREUD, 2010, p. 50).

Para Freud (2010), os indivíduos teriam seus impulsos e desejos reprimidos na vida social, já que a vida em sociedade se imporia como necessidade, o que nos conduziria aos 
sentimentos de frustração, culpa e exigências e a uma noção de consciência moral. Para vivermos coletivamente, precisaríamos recalcar os restos, o avesso do que aconteceria na sexualidade animal. Viver seria uma sensação de mal-estar permanente, na constatação sobre nosso profundo desamparo diante das dores e horrores de uma cultura violenta, nas formas de lidar com nossos próprios impulsos agressivos e com o conflito permanente de nossas próprias frustrações. Nesse sentido, o princípio do prazer seria a sensação provisória de bemestar, pois como o próprio autor reconhece, “[...] nossos desejos se estendem para além de nosso prazer" (2010), se deslocando para outros lugares depois de realizados. A certeza da morte seria a constatação mais radical sobre a tendência do corpo à destruição e ao aniquilamento. É nesse sentido que a felicidade não seria algo durável, fazendo com que Freud postulasse a ideia de que não seríamos seres afeitos à felicidade.

Essas questões fundamentais - e bastante sintetizadas em relação à importância da psicanálise para os filósofos citados - nos parecem particularmente adequadas quando pensamos a filmografia de Woody Allen, já que seus filmes exploram com frequência essas remissões a Freud e aos temas da angústia e do sofrimento humano, mesclando percepções sobre a consciência moral, a culpa e a melancolia que atravessam este profundo mal-estar da civilização e das próprias personagens de seus filmes. Em vários de seus filmes, o diretor recorre à potência dos sonhos e da hipnose como motes para suas tramas, revelando a potencialidade do cinema para representar o universo onírico. Ao longo desta densa e divertida filmografia, acabamos encontrando respaldo no postulado freudiano de que as artes, assim como o amor, as drogas e a religião, seriam filtros indispensáveis de esquecimento, distrações poderosas que abarcariam extenso potencial catártico, uma espécie de união entre terror e libido (FREUD, 2010).

Wittgenstein dialoga com a prática psicanalítica para pensar a filosofia e a linguagem e sugere noções como as de jogos de linguagem, semelhanças de familia e formas de vida para propor um movimento remissivo e alusivo, bem próximo daquele realizado pela análise terapêutica, que poderia ser compreendido fora da lógica clássica e racional do modelo causa-efeito e que mais se aproximaria do interesse de se investigar como determinados problemas se constituem e se dissolvem com base no poder dos jogos de linguagem de induzir-nos a vêlos e a configurá-los segundo imagens fixas, inadequadas ou ilusórias. Assim como os teóricos críticos, Wittgenstein foi avesso ao projeto civilizatório do expansionismo europeu moderno e a toda sua ideologia, baseada na crença do progresso científico, na existência de uma história progressiva e na visão liberal, mercantilista, patriarcal e hierarquizada do mundo e das formas de vida. O filósofo criticou o desejo de racionalização das crenças e de dogmatização da ciência, recusando-se a acessar qualquer coisa que dependesse do uso de uma escada ${ }^{2}$. É este mesmo projeto civilizatório que será amplamente questionado por autores como Walter Benjamin, Theodor Adorno e Max Horkheimer, no contexto da ascensão dos regimes autoritários na Europa, das perseguições aos corpos dissidentes e dos consequentes genocídios massificados que seguiram seu curso, ao longo do século XX.

Como esclareceram Adorno e Horkheimer (1985), as expectativas da tradição cartesiana de que cada sujeito seria capaz de compreender a natureza e de dominá-la de acordo com seus próprios interesses, desde que organizasse sua capacidade de pensar racionalmente, não se cumpriram, especialmente quando observamos as guerras, as

\footnotetext{
2 "Tudo aquilo que se pode alcançar com uma escada não me interessa" (WITTGENSTEIN, 2000, p. 21).
} 
experiências mundiais do horror do holocausto e da ascensão nazista, que evidenciaram o emprego instrumental da razão pela barbárie e o desprezo à ética nas práticas cotidianas. No ensaio, Educação após Auschwitz. (1995), a insistência de Adorno é a de que a educação trabalhe para que Auschwitz não se repita, evidenciando que grande parte dos intelectuais e cientistas de sua época compactuaram com a violência e financiaram a barbárie dos campos de concentração. Em momento anterior, em um de seus aforismos, Wittgenstein também questiona a ciência, propondo que a crença não científica no mundo seria mais próxima de uma experiência mística, de um ato de fé e vontade: “[...] se queremos lutar, lutemos! Se queremos ter esperança, tenhamos esperança! Podemos lutar, ter esperanças e até mesmo acreditar, mas sem acreditar cientificamente" (WITTGENSTEIN, 2000, p. 92). Para o autor, este questionamento passaria pela confiança arbitrária no poder normativo de nossos jogos compartilhados de linguagem (MIGUEL, 2018).

\section{Match Point: crimes, castigos e pecados}

Em Match Point (2005), Woody Allen elabora com maior densidade dramática um tema já explorado por ele desde Crimes e Pecados (1989), uma espécie de transposição do dilema dostoievskiano vivido pelo jovem personagem Ródion Raskólnikov em Crime e Castigo (1866). No romance, o protagonista é um estudante pobre e angustiado, “[...] esmagado pela pobreza” (DOSTOIÉVSKI, 2001, p. 19), que dá aulas particulares para custear seus estudos na universidade, mas é obrigado a abandoná-la em função das dificuldades econômicas de toda a família e das pessoas de sua convivência próxima. Todos ao seu redor, inclusive ele próprio, são explorados pela velha usurária Aliena Ivánovna, que empresta dinheiro a juros de agiota em troca de objetos familiares empenhados a preços irrisórios. Como é notório aos leitores de Dostéievski, suas personagens, sempre na iminência da morte, possuem consciência radical da condição de humilhadas e ofendidas e reagem a esta condição com o desespero daqueles que precisam preservar o pouco que lhes resta, a própria dignidade.

Fiódor Dostéievski recriou o imaginário de sua época a partir da construção do universo particular e específico de suas personagens, denunciando a decomposição da nobreza e a decadência moral da burguesia. Como recordou Paulo Bezerra, no prefácio da edição de Crime e Castigo (2001), as reflexões sobre a questão do limite - componente central da composição de Dostoiévski - remetem às polêmicas teses centrais do iluminismo que

[...] têm como pano de fundo a civilização burguesa oriunda desse movimento, que incorporou os piores exemplos de violência da história e na qual o homem "talvez chegue ao ponto de encontrar prazer em derramar sangue", "os mais refinados sanguinários foram todos cavalheiros civilizados" e "são encontrados com demasiada frequência, são por demais comuns e já não chamam atenção", porque seus atos sanguinários já viraram hábito, isto é, passaram a integrar a própria civilização. Essas reflexões estão em profunda sintonia com a análise que Raskólnikov faz da história e com sua teoria do crime permitido (DOSTOIÉVSKI, 2001, p. 11).

A civilização burguesa criou seres humanos guiados primordialmente pela razão, indivíduos conformados não apenas com o limite imposto às suas ações, como também com o temor de imaginar formas de ultrapassá-lo, em função de possíveis consequências punitivas e do imaginário de terríveis sacrifícios aos quais estariam condenados. O "homem do 
subsolo", como pontua Bezerra em referência a outro romance do autor, Memórias do Subsolo (DOSTOIÉVSKI, 2009), desdenhou deste modelo de ser guiado pela racionalidade e pelo interesse, em defesa do direito de viver segundo sua própria vontade, pautada pelo livrearbítrio. De maneira semelhante pensava o protagonista de Crime e Castigo, ao associar a figura de Napoleão Bonaparte à sua teoria sobre os indivíduos extraordinários, alguém que derramou rios de sangue para consolidar este projeto de civilização burguesa que tem o sistema bancário como símbolo maior de sua existência. Ainda assim, constatou Raskólnikov, a história o absolveu.

Esse aparente paradoxo que se inaugura com a ascensão do capitalismo financeiro é percebido pelas contradições do comportamento de personagens como Raskólnikov, que em alguns momentos do romance transita entre uma figura fortemente solidária e um ser embrutecido e sem nenhuma compaixão ${ }^{3}$. No decorrer do enredo, acontece um encontro inesperado entre o ex-estudante que, ao entrar pela primeira vez em uma taberna, inicia uma conversa com um senhor bêbado, que lembrava um funcionário público aposentado. Como num ato casual, o narrador nos conta sobre a primeira impressão que o velho e desamparado Marmieládov produziu em Raskólnikov e que seria mais tarde recordada por ele como um pressentimento: “Acontecem certos encontros com pessoas que desconhecemos inteiramente, por quem começamos a nos interessar à primeira vista, como que de repente, súbito, antes que articulemos uma palavra" (DOSTOIÉVSKI, 2001, p. 28). Aquele homem - velho, bêbado, pobre, sujo, melancólico, esfarrapado e desacreditado entre os demais daquele recinto - possuía algo muito estranho e peculiar, um olhar que irradiava "um quê de entusiasmo", uma mescla entre sentido, inteligência e loucura. Raskólnikov estava perturbado e faminto quando alguma coisa o impeliu até aquele local, era a primeira vez que lhe ocorrera o aparente absurdo e repugnante pensamento sobre o assassinato da velha usurária. Ele reconheceu, naquele mesmo instante, a figura do homem, cujo estado de agitação e solidão, inconscientemente, poderia representar uma perspectiva se seu próprio futuro, uma imagem de si mesmo. Em contrapartida, os olhos experientes de Marmieládov enxergaram e distinguiram Raskólnikov naquele mesmo instante em meio à insensível multidão, como se pudesse antever o estado do protagonista e eleger aquele que seria a pessoa certa para ouvir suas trágicas memórias:

- Meu caro senhor - retomou ele em tom quase solene -, pobreza não é defeito, e isto é uma verdade. Sei ainda mais que bebedeira não é virtude. Mas a miséria, meu caro senhor, a miséria é defeito. Na pobreza o senhor ainda preserva a nobreza dos sentimentos inatos, já na miséria ninguém o consegue, e nunca. Por estar na miséria um indivíduo não é nem expulso a pauladas, mas varrido do convívio humano a vassouradas para que a coisa seja mais ofensiva; o que é justo, porque na miséria eu sou o primeiro a estar pronto para ofender a mim mesmo. Daí o botequim! [...] (DOSTOIÉVSKI, 2001, p. 30).

Certas falas do pobre Marmieládov adquirem tom quase profético ao drama do protagonista, como a repetição de que "é preciso que qualquer um possa ir pelo menos a

\footnotetext{
${ }^{3}$ Faço referência aqui à passagem em que o protagonista encontra uma moça bêbada na rua e, mesmo sem conhecê-la, decide ajudá-la, oferecendo dinheiro a um policial para escoltá-la com segurança até sua casa, temendo que pudesse ser abusada por um senhor "almofadinha" que a perseguia. Mas, na sequência, Raskólnikov muda subitamente de opinião ao afirmar que, na verdade, ninguém teria nada a ver com a situação, mostrando não se importar mais e tentando reaver seu dinheiro, afinal, se não tinha condições nem de manter-se a si próprio, como poderia ajudar alguém? (DOSTOIÉVSKI, 2001, p. 65).
} 
algum lugar", "há momentos em que é preciso ir sem falta pelo menos a algum lugar!", repetições que encontram eco no próprio pensamento de Raskólnikov, que antecedia sua chegada à taberna. Por uma segunda vez, o velho ironiza a ciência, lembrando de um tal senhor Liebeziátnikov que espancou sua esposa. A conversa, casualmente, toca enfim no assunto sobre empréstimo de dinheiro e, em certo momento, o senhor diz o seguinte:

- Permita-me perguntar, meu jovem, já lhe aconteceu... hum... bem, pelo menos pedir dinheiro emprestado sem esperança?

- Aconteceu... mas como sem esperança?

- Isso mesmo, sem qualquer esperança, sabendo de antemão que nada vai conseguir. Você sabe, por exemplo, de antemão e em detalhes que essa pessoa, o mais bemintencionado e o mais útil dos cidadãos, não lhe vai emprestar de jeito nenhum, pois, pergunto eu, por que iria emprestar? Ora, já sabe que eu não vou pagar. Por compaixão? Mas o senhor Liebeziátnikov, em dia com as novas ideias, explicou há pouco que a compaixão em nossa época está proibida até pela ciência e que já é assim que se procede na Inglaterra, onde existe a economia política. Por que, pergunto eu, emprestaria? Pois bem, mesmo sabendo de antemão que não vai emprestar, ainda assim você se põe a caminho e [...] (DOSTOIÉVSKI, 2001, p. 31).

A partir da fala do personagem, observamos como o sentimento da compaixão humana perdeu seu lugar nesses novos tempos civilizatórios, centrados no princípio da razão, em nome dos quais construímos nossas certezas modernas. Ao longo do romance, Raskólnikov é constantemente atravessado pelas contradições e conflitos inerentes ao surgimento desses novos tempos, o que parece se tornar mais intenso quanto mais indigna vai se tornando sua própria condição de vida. O drama moral do protagonista se esboça logo nas primeiras vezes em que ele cogita involuntariamente a possibilidade de assaltar e assassinar Aliena Ivánovna, saindo transtornado do prédio após receber uma quantia irrisória pela penhora de um relógio:

Oh, Deus! Como tudo isso é repugnante! Será possível... será possível que eu... Não, isso é um absurdo, um contrassenso! - acrescentou decidido. - Será possível que tamanho horror me tenha ocorrido? Contudo, de que baixeza meu coração é capaz! O principal: isso é sórdido, nojento, abjeto, abjeto... e eu, um mês inteiro [...] (DOSTOIÉVSKI, 2001, p. 26).

Dostoiévski representou, como poucos, as tramas psicológicas que tensionam os limites da ação humana, tendo não apenas este limiar como componente central das narrativas, mas também os conflitos ideológicos e os debates filosóficos, éticos e políticos. Bakhtin o considerou um dos maiores romancistas da literatura russa, o mais inovador de todos os tempos, criador de um universo permeado de discussões sobre o pensamento e o comportamento humanos, chamando inclusive a atenção para os aspectos profundamente polifônicos e dialógicos de seus contos, novelas e romances (BAKHTIN, 2008). Em carta escrita a uma amiga, Dostoiévski se autodefine da seguinte maneira: “[...] eu sou filho do século, filho da descrença e da dúvida; assim tenho sido até hoje e o serei até o fim dos meus dias. Que tormentos terríveis tem me custado essa sede de crer, que é tão mais forte em minha alma quanto maiores são os argumentos contrários" (DOSTOIÉVSKI, 2001, p. 13).

Como outros personagens dostoievskianos, Raskólnikov é um jovem sensível, profundamente erudito e intelectualizado para sua pouca idade. Toda a trama do assassinato 
planejado e executado por ele, ao longo do romance, é concebida, portanto, a partir do imaginário ateu e niilista ${ }^{4}$ daquele contexto, afinal, se Deus não existe, tudo seria permitido, até mesmo matar a velha agiota que encarnaria, na microestrutura, toda a exploração humana que o sistema bancário produz, a serviço do capitalismo, na macroestrutura. Esta constatação é uma paráfrase recorrentemente utilizada pelos leitores e estudiosos da obra de Dostoiéviski, retirada de pelo menos mais dois de seus romances. Em Os Demônios (2004), o perturbado e lógico personagem, Kiríllov, fala sobre a existência do arbítrio do sujeito: "Se Deus existe, então toda vontade é Dele, e fora da vontade Dele nada posso. Se não existe, então toda vontade é minha e sou obrigado a proclamar meu arbítrio" (DOSTOIÉVSKI, 2004, p. 598). Em seu último romance, Os Irmãos Karamázov (2012), esta mesma questão reaparece ficcionalizada. Assim como em "Crime e Castigo", este romance retoma uma série de temas e preocupações presentes em obras anteriores do autor, tais como, a trama do crime hediondo; a investigação policial detetivesca; o júri explanatório; a culpa e as reflexões sobre a fé e a religião, atreladas aos dramas familiares de quatro irmãos que se tornam suspeitos da morte do pai, um homem interesseiro e odiado por eles.

Em "Dostoiévski e o parricídio" (2014), Freud considerou este último romance do autor como sua obra prima mais célebre. O psicanalista chega a admitir que "[Dostoiévski] não pode ser compreendido sem a psicanálise - isto é, ele não tem necessidade dela, porque ele próprio a ilustra em todos os personagens e em todas as frases” (FREUD, 2014, p. 333). $\mathrm{Na}$ verdade, esta constatação do pai da psicanálise admite a evidência de não terem sido os psicólogos ou cientistas aqueles que mais se mostraram capazes de penetrar com profundidade na alma moderna. Neste mesmo artigo, Freud comenta que o poema "O grande Inquisidor", que integra o mesmo romance, configuraria um dos pontos mais altos da literatura mundial, sendo dotado de "valor incomparável".

Especialmente as características do irmão do meio, Ivan Fiodorovitch Karamázov, se aproximam do perfil do protagonista de Crime e Castigo e de alguns personagens criados por Woody Allen em seus filmes, especialmente do protagonista de Match Point. Ivan é um fino e manipulador intelectual de convicções ateias, atormentado pelos dilemas de sua erudição e que transgride as regras de moralidade. Retomando aquela mesma ideia central a de que se Deus não existe, tudo seria permitido - temos ainda um fragmento de Os irmãos Karamázov (2012) em que o narrador comenta as considerações sobre um artigo que Ivan publica em uma revista, dizendo o seguinte:

[...] ele declarou em tom solene que em toda a face da terra não existe absolutamente nada que obrigue os homens a amarem seus semelhantes, que essa lei da natureza, que reza que o homem ame a humanidade, não existe em absoluto e que, se até hoje existiu o amor na Terra, este não se deveu a lei natural mas tão-só ao fato de que os homens acreditavam na própria imortalidade. Ivan Fiodorovitch acrescentou, entre parênteses, que é nisso que consiste toda a lei natural, de sorte que, destruindo-se nos homens a fé em sua imortalidade, neles se exaure de imediato não só o amor como também toda e

\footnotetext{
${ }^{4}$ Dostoiévski postula, em seus romances, esta modernidade tardia ou niilista, caracterizada pela desintegração da família e das instituições sociais, marcada pela ideia de que que cada um poderia gozar da própria liberdade individual e pela dessacralização ou destruição da crença nas regras, até então reconhecidas como universais. Ao desvendar o assassinato de Raskólnikov, o inspetor da polícia, Porfiri Pietróvitch, constata o seguinte: "quem entre nós na Rússia não se considera hoje um Napoleão?” (Dostoiévski, 2001, p. 274). Nietzsche, que também foi leitor dos escritores russos, nas últimas décadas do século XIX, discute este termo usado por Dostoiévski: "Descrevo o que vem, o que já não pode vir de outra maneira: o advento do niilismo [...]. Toda a nossa cultura europeia se move já há algum tempo sob uma tensão torturante que cresce década a década como que se destinada a uma catástrofe: inquieta, violenta, precipitada” (NIETZSCHE, 2008, p. 489).
} 
qualquer força para que continue a vida no mundo. E mais: então não haverá mais nada amoral, tudo será permitido, até a antropofagia. Mas isso ainda é pouco, ele concluiu afirmando que, para cada indivíduo particular, por exemplo, como nós aqui, que não acreditamos em Deus nem na própria imortalidade, a lei moral da natureza deve ser imediatamente convertida no oposto total da lei religiosa anterior, e que o egoísmo, chegando até ao crime, não só deve ser permitido ao homem mas até mesmo reconhecido como a saída indispensável, a mais racional e quase a mais nobre para a situação (DOSTOIÉVSKI, 2012, p. 109).

Ainda durante uma célebre passagem de Os irmãos Karamázov, Ivan narra a seu irmão Aliéksiei uma poesia que está escrevendo, justamente "O grande Inquisidor", comentada por Freud. Este inquisidor, que assume a figura do diabo, ao se deparar com Jesus que acaba de voltar à Terra, questiona: "Será que não pensaste que ele (o ser humano) acabaria questionando e renegando até tua imagem e tua verdade se o oprimissem com um fardo tão terrível como o livre arbítrio? (DOSTOIÉVSKI, 2012, p. 353). Em momento muito posterior do romance, o personagem considera uma outra possibilidade, desta vez sobre o que aconteceria se Deus não existisse e a religião fosse extinta:

Quando a humanidade, sem exceção, tiver renegado Deus (e creio que essa era virá), então cairá por si só, sem antropofagia, toda a velha concepção de mundo e, principalmente, toda a velha moral, e começará o inteiramente novo. Os homens se juntarão para tomar da vida tudo o que ela pode dar, mas visando unicamente à felicidade e à alegria neste mundo. O homem alcançará sua grandeza imbuindo-se do espírito de uma divina e titânica altivez, e surgirá o homem-deus. Vencendo, a cada hora, com sua vontade e ciência, uma natureza já sem limites, o homem sentirá assim e a cada hora um gozo tão elevado que este lhe substituirá todas as antigas esperanças no gozo celestial. Cada um saberá que é plenamente mortal, não tem ressurreição, e aceitará a morte com altivez e tranquilidade, como um deus. Por altivez compreenderá que não há razão para reclamar de que a vida é um instante, e amará seu irmão já sem esperar qualquer recompensa. $\mathrm{O}$ amor satisfará apenas um instante da vida, mas a simples consciência de sua fugacidade reforçará a chama desse amor tanto quanto ela antes se dissipava na esperança de um amor além-túmulo e infinito (DOSTOIÉVSKI, 2012, p. 840).

Em Crime e Castigo, Raskólnikov cria uma engenhosa teoria dos indivíduos, em que as pessoas seriam divididas entre ordinárias - condenadas a viver de resiliência e conformação - e extraordinárias, estas sim capazes de levar a sociedade a algum estágio de transgressão. Nesse sentido, alguns crimes poderiam ser aceitáveis moralmente, desde que visassem a um bem maior, como a sobrevivência. A morte premeditada da velha usurária ganharia assim um motivo nobre: livrar a humanidade daquela pessoa horrorosa e exploradora. Assim, conseguiria dinheiro para ajudar a mãe, que ganhava uma pensão escassa; a irmã, desempregada após sofrer assédio sexual de um rico senhor de terras, na casa onde trabalhava como governanta; e ser capaz de continuar seus estudos. Os passos até então premeditados do crime são, porém, comprometidos por um detalhe casual, quando o protagonista, após matar a senhora a machadadas, acaba sendo obrigado a assassinar também a irmã da vítima, que por um golpe de azar apareceu no local naquele exato momento. A partir deste duplo assassinato, o romance explora o drama psicológico do remorso e da crise de consciência, neste doloroso e conflitante processo de culpa e castigo imposto pela sociedade e pela conduta subjetiva do protagonista até a sua confissão. 
Processo semelhante ao que acontece com Raskólnikov é o que os expectadores acompanham na construção dos enredos e dos protagonistas de Crimes e Pecados e Match Point, sentimentos evidentemente conflitantes, pois torcemos estranhamente pelos personagens, ainda que sejam eles assassinos brutais - seja apenas premeditando o crime, como acontece com o médico oftalmologista de Crimes e Pecados, seja também executando os assassinatos, como nos demais casos - que aceitaram transgredir os limites da vida, violar as regras de conduta social, assumindo os riscos das probabilidades de qualquer punição. No entanto, cada caso precisaria ser analisado a partir de um olhar distinto, ainda que estejamos diante de crimes bárbaros de feminicídio. Talvez, o que nos aproxime desses personagens, em todos os casos, seja a profunda ironia crítica construída por essas narrativas, não apenas de evidenciar que seus protagonistas masculinos não fazem parte do grupo de indivíduos extraordinários, capazes de cometer quaisquer crimes ou de infringir as regras morais sem algum possível sentimento de culpa, mas principalmente de nos fazer experimentar a dúvida sobre a possibilidade de punição e o desempenho do imprevisível diante das evidências categóricas, elevando esses temas à condição de categoria estética. Essas reflexões existenciais sobre a culpa, sobre a existência ou inexistência de Deus e da justiça são tensionadas para evidenciar os antagonismos sociais e a naturalização das violências praticadas pelas classes dominantes, metonimicamente representadas pela impossibilidade de punição dos protagonistas de ambos os filmes de Woody Allen: assim como as narrativas historiográficas dos vencedores, aludidas por Raskólnikov em sua referência à Napoleão, os enredos finalizam com a manutenção desta mesma lógica, já que seus protagonistas são igualmente absolvidos de qualquer punição da justiça.

A cena alegórica inicial de Match Point (ALLEN, 2005) é marcantemente representativa da discussão proposta ${ }^{5}$. Temos ali uma série de instâncias narrativas (XAVIER, 2008) operando de maneira curiosa na construção de sentidos para o todo da narrativa fílmica. No plano visual, a câmera centraliza a rede de uma quadra de tênis, apontando para este limite demarcatório fundamental entre cada um dos lados ocupados pelos intencionalmente ocultos jogadores.

Figura 04 - Cena do filme Mach Point (2005), de Woody Allen.

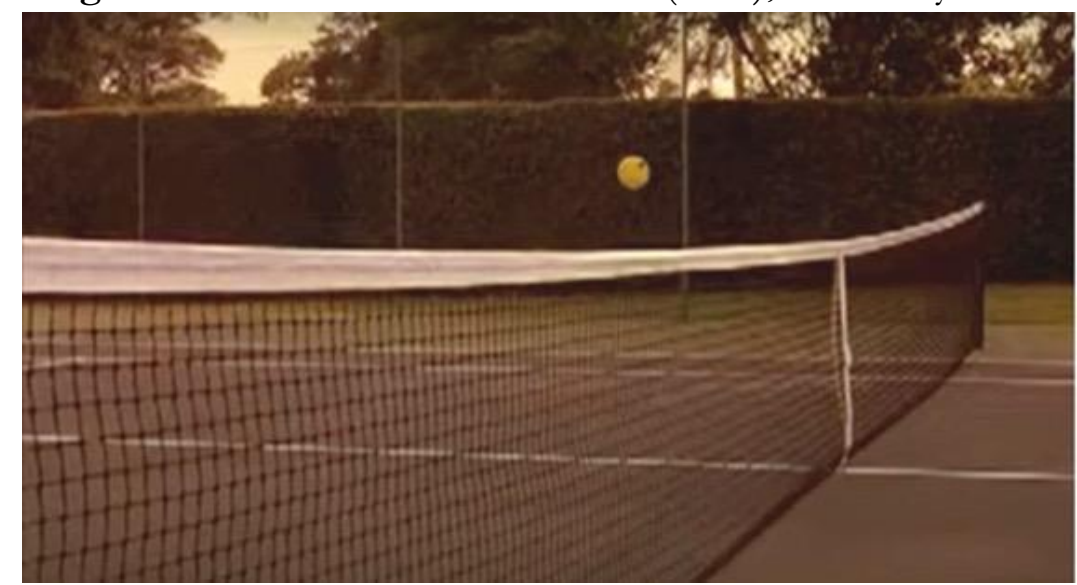

Fonte: (ALLEN, 2005).

\footnotetext{
${ }^{5}$ Esta cena pode ser visualizada no link: https://www.youtube.com/watch?v=QGVHgYQPNJU
} 
Assistimos, em câmera lenta, a uma partida de tênis, através da imagem da bola que se movimenta de um lado a outro. Enquanto isso, outra instância opera a trilha sonora que ambienta a cena, ao ouvirmos o trecho inicial da ária "Una Furtiva Lagrima" - uma lágrima sombria, na tradução em português - que participa do último ato da ópera L'Elisir D'Amore, de Gaetano Donizetti. Nesta ópera de Donizetti, o elixir que desperta amor é uma alusão satírica à ópera Tristão e Isolda de Wagner e ao romance de cavalaria de título homônimo, de autoria desconhecida. O libreto conta a história de amor entre um camponês que acredita que a paixão de uma jovem nobre por ele teria sido fruto da poção mágica que lhe havia sido vendida por um charlatão. No final da ópera, o casal apaixonado se casa e ele descobre ter se tornado um homem rico, através de uma herança que recebeu inesperadamente (BAPTISTA FILHO, 1987).

Dessa forma, a imagem visual da rede e do jogo de tênis sobreposta à imagem sonora a que nos remete o enredo da ópera funcionam como metáforas fundamentais que antecipam ao espectador os grandes temas da trama a ser narrada. Uma terceira instância narrativa se sobrepõe às anteriores, quando a voz do protagonista, em off, diz o seguinte:

Quanto de imponderável ou quanto de escolha tem a vida? O homem que diz preferir ter sorte a ser bom, entendeu bem a vida. As pessoas têm medo de admitir que grande parte da vida depende da sorte. É assustador pensar que grande parte das coisas estão fora do nosso controle. Há momentos numa partida em que a bola toca no topo da rede, e por um milésimo de segundo pode ir para frente ou cair para trás. Com um pouco de sorte a bola segue em frente e você vence. Ou talvez não... e você perde (ALLEN, 2005).

Esta cena inicial, que dará o mote para toda a trama do filme, nos remete a alguns aforismos de Wittgenstein sobre a imprevisibilidade dos jogos de linguagem, bem como à impossibilidade de se distinguir claramente quando deixamos de jogar um jogo e passamos a jogar outro. Para o filósofo, as linguagens não se assemelham a jogos apenas em seus aspectos cênico-performativos ou regrados, mas também em seus aspectos de imprevisibilidade em relação à contemplaçñao de propósitos comuns ou diferenciais que movimentam os jogadores que deles participam, ainda que nem todos os jogos de linguagem possuam uma característica comum ou sejam orientados por regras ou propósitos claramente definidos:

Ou há, em qualquer lugar, um ganhar e perder ou uma competição de jogadores? Pense no jogo de paciência. Nos jogos com bola há ganhar e perder; mas quando uma criança arremessa a bola na parede e a pega de novo, então, esse traço se perde. Veja que papel desempenham a habilidade e a sorte.E como é diferente a habilidade no jogo de xadrez e no jogo de tênis. (WITTGENSTEIN, 1979, IF 66).

O que ainda é um jogo e o que não é mais? Você pode assinalar os limites? Não. Você pode traçar algum: pois ele ainda não está traçado. [...]. - Ele não está inteiramente delimitado por regras. Não há, por exemplo, qualquer regra, no tênis, que prescreva até que altura é permitido lançar a bola e nem com quanta força; mas o tênis é um jogo e também tem regras (WITTGENSTEIN, 1979, IF 68).

Mas a cena inicial de Match Point se assemelha, sobretudo, à reflexão que Wittgenstein realiza em duas outras passagens consecutivas das Investigaçôes Filosóficas, acerca de como costumamos nos comportar diante de uma "perturbação imprevista", isto é, quando uma 
situação com a qual estamos envolvidos escapa completamente ao nosso controle e fica suspensa no ar, como quando uma bola de tênis “[...] toca no topo da rede e, por um milésimo de segundo, pode ir para frente ou cair para trás":

\begin{abstract}
"Agora eu sei continuar!" é uma exclamação; ela corresponde a um som natural, a um frêmito de alegria. Dessa minha sensação não se segue, naturalmente, que eu não possa travar quando tentar prosseguir. Há casos em que direi: - "Quando disse que sabia continuar, era isso mesmo". Costumamos dizer isso, por exemplo, quando ocorre uma perturbação imprevista. Mas o imprevisto não deveria ser simplesmente visto como o fato de eu ter travado quando tentava prosseguir. Poderíamos também pensar que alguém que tivesse continuamente supostas revelações dissesse: - "Agora sei como continuar!", mas não pudesse justificar isso pelos seus atos. - Para essa pessoa, a impossibilidade de prosseguir poderia ser vista como se ela tivesse momentaneamente se esquecido do significado da imagem que lhe permitiria prosseguir. Seria correto dizer, neste caso, tratar-se de uma certeza obtida por indução, e de que eu estaria tão seguro de que poderia prosseguir, por exemplo, uma série numérica, como seguro estou de que este livro [esta bolinha, diria o narrador do Match PoinA cairá no chão se eu o largar [cairá de um lado ou de outro da rede, diria o narrador]. Mas, não seria surpreendente se, de repente, sem causa evidente, eu não soubesse como continuar uma série numérica, tanto quanto o seria se o livro [a bolinha de tênis], em vez de cair, ficasse suspenso no ar? - A isto, eu responderia que também não precisamos de motivos ou razões para esta certeza. O que poderia justificar mais a certeza do que a constatação do resultado surpreendente? (WITTGENSTEIN, 1979, IF-324, grifo nosso).
\end{abstract}

Match Point, como propõe o título do filme, é o ponto final e decisivo de uma partida de tênis e a narrativa orbita justamente ao redor da história de um ex-jogador americano, Chris Wilton, que se transforma em professor de um clube da alta burguesia londrina. Todo o filme é contado, portanto, a partir da ótica deste personagem que nos narra sua própria história. Sua fala inicial é sobreposta à imagem da bola de tênis no momento exato em que ela toca o topo da rede em câmera lenta, neste instante indecidível e imponderável formulado pelo narrador, em que somos tomados pela certeza indutiva de que a bolinha não ficará suspensa no ar e que, portanto, independentemente da habilidade do jogador e tão somente do desejo do acaso, apenas duas coisas podem acontecer: ou se vence ou se ganha a partida.

$\mathrm{Na}$ retomada direta de Crime e Castigo, a partir da teoria do crime permitido e na divisão que Raskólnikov cria entre indivíduos ordinários e extraordinários, o personagem Chris utiliza a metáfora imaginária da rede de tênis para indicar sua crença de que o acaso dividiria a vida entre perdedores e ganhadores. Ele acredita na sorte enquanto uma virtude mais valorosa do que a bondade e, por obra do acaso, conhece Tom Hewett e sua irmã Chloe, filhos de um rico empresário.

Chris é leitor de Dostoiévski e das tragédias de Sófocles, jogador de tênis e frequentador de óperas, expressão de um refinamento cultural que acaba sendo seu passaporte de aceitação entre os círculos da família tradicional aristocrática inglesa, dentre elas, a família Hewett que, ao notar os seus modos e interesses culturais, acaba permitindo o relacionamento amoroso entre ele e a filha Chloe. Ao frequentar, porém, a casa da família do empresário, Chris se apaixona perdidamente por Nola, uma belíssima jovem norteamericana, interpretada por Scarlett Johansson, que tenta ganhar a vida como atriz e é também a namorada de Tom, irmão de Chloe. A mãe de Tom desaprova o relacionamento em função do desajuste da moça aos padrões e aos códigos de conduta esperados por aquela 
sociedade. Nola, além de atriz, está desempregada, ousa em seus figurinos, fuma, bebe e é extremamente sedutora e passional.

Outro momento interessante em que o acaso se manifesta no filme é a cena do jantar entre os casais: enquanto Nola avalia o fato de sua carreira como atriz não estar indo como ela esperava, Chris expressa sua crença na importância definitiva da sorte para qualquer aspecto da vida. Para ele, não haveria nenhum sentido para a vida, já que estamos no mundo devido a um puro golpe do acaso. Sua noiva, Chloe, desdenha da sorte, afirmando que ela só aparece depois do "trabalho duro". Chris então confirma a ideia de que o trabalho é mesmo fundamental, mas não é ele unicamente que definiria o sucesso ou insucesso de uma carreira. Ao contrapor os hábitos ingleses e os gostos refinados dos irmãos Hewett - expressos pelos seus pedidos gastronômicos - aos dos estrangeiros Nola e Chris, a cena acaba tensionando também os limites entre as classes sociais e o deboche das classes dominantes ao gosto popular e, por extensão, reforçando a possibilidade da relação de atração entre iguais, entre atriz e professor. Ao tematizar a questão da sorte, o diálogo conduz o argumento central do protagonista à possibilidade de pensarmos sobre o acaso e o destino e de refletirmos novamente sobre o par tensional que se estabelece entre o livre-arbítrio e o determinismo.

Em Match Point, aquilo que poderia ser reconhecido como uma ação do acaso acontece em pelo menos duas situações bem demarcadas: a primeira, se desdobra em golpe de azar, quando os planos do assassinato da amante saem do rigorosamente premeditado e Chris é obrigado a matar também a vizinha de Nola, roubando suas joias no intuito de simular um assalto a mão armada. Já a segunda, é construída com engenhosidade estética, na cena em que o protagonista se desfaz dos pertences da velha senhora, atirando-os no rio Tâmisa. Como mostra a imagem a seguir, a aliança de ouro bate no parapeito da ponte - parapeito que, por uma coincidência casual, tem a forma de uma rede de tênis -, remetendo-nos de volta - e agora, intencionalmente - à cena inicial do filme: em vez da bola de tênis, agora é a simbólica aliança que sobe em câmera lenta, reacendendo o suspense em relação ao possível destino do criminoso, já que o anel poderia cair ou do lado-rio do parapeito-rede e nunca mais ser encontrado, ou então, cair do lado-rua e se tornar uma pista-prova do assassinato.

Figura 05 - Cena do filme Mach Point (2005), de Woody Allen.

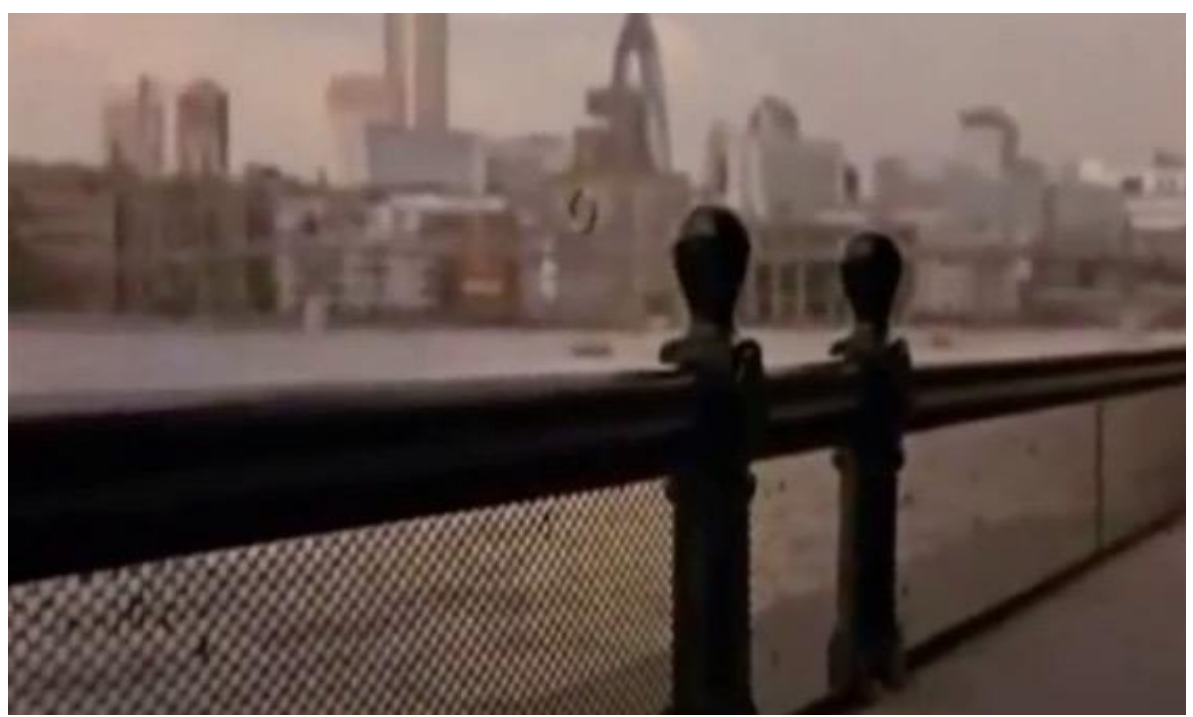

Fonte: (ALLEN, 2005) 
$\mathrm{Na}$ sequência, a aliança acaba retornando no sentido oposto ao do movimento intencional do criminoso, no intuito de livrar-se dela, sendo posteriormente encontrada por um mendigo na sarjeta. Entretanto, a ironia se constrói com imprevisibilidade radical, pois o retorno do anel cria no espectador um sentimento de mal presságio, como se a ação do acaso fosse necessariamente resultar em um novo golpe de azar para o assassino. No entanto, ao contrário, o acaso desta vez se transmuta em golpe de sorte, favorecendo o assassino e desfavorecendo o mendigo: como já possuía ficha na polícia, o mendigo que encontra o anel acaba sendo preso e culpado pelos homicídios. Chris acaba sendo liberado da condição de suspeito, permanecendo impune de seus atos mais condenáveis. Em meio ao trágico enredo - reencenado dentro da própria trama pela trilha sonora e pela ópera assistida pelos personagens -, a comicidade fica por conta das figuras dos detetives que investigam o caso: um deles, através de um sonho, é encaminhado certeiramente para a evidência de sua solução, mas acaba abandonando a teoria onírica em nome da falsa prova jurídico-científica representada pelo anel encontrado no bolso do mendigo.

Woody Allen constrói uma transposição da dor moral vivida por Raskólnikov, no romance de Dostoiévski, e transforma esse dilema moral em motivações bastante diferentes daquelas apresentadas por Chris em Match Point, em suas ações oportunistas. Embora sua consciência se mostre igualmente atormentada, como aponta a fantasmagoria do sonho, em que ele confessa sua culpa diante de suas vítimas, o personagem admite que não será punido e que, se assim o fosse, seria possível acreditar em alguma esperança possível de justiça e de sentido na existência. A cena final do filme mostra a comemoração em família, em que esposa, sogros e cunhados do protagonista celebram o nascimento do filho do casal. Enquanto todos brindam, Chris se mantem distante e melancólico, tomado pela consciência em relação à tragicidade da existência. Enquanto o pai de Chloe diz: "que esse menino seja grande em tudo a que se propuser", Tom arremata a cena com o seguinte brinde: "não me interessa que ele seja grande, só espero que tenha sorte".

\section{Como foi dito: não pense, veja! ${ }^{6}$}

A cena inicial de Match Point nos remete, por semelhanças de família, a outra cena antológica do cinema, desta vez retirada do filme Blow-Up - Depois Daquele Beijo (1966), do diretor italiano Michelangelo Antonioni. A remissão, inicialmente, é construída pelo jogo de encenação dos personagens, um grupo de mímicos que finge jogar uma partida de tênis no parque onde o jovem fotógrafo Thomas fotografava, casualmente, cenas ao redor. Os personagens encenam a representação dos jogadores a partir do movimento de uma bola invisível aos olhos dos espectadores. Esta cena produz um estranhamento inicial proposital, capaz de antecipar o tema da invisibilidade do olhar: este mesmo cenário será também o local de um misterioso crime que será descoberto pelo protagonista através da ampliação das fotos posteriormente reveladas em seu estúdio de moda. Também aqui, o jogo de tênis participa da cena como metáfora engenhosa para simbolizar que o acaso participa do jogos da vida.

${ }^{6}$ (WITTGENSTEIN, 1979, IF-66). 
Figura 06 - Blow-Up - Depois Daquele Beijo (1966), de Michelangelo Antonioni

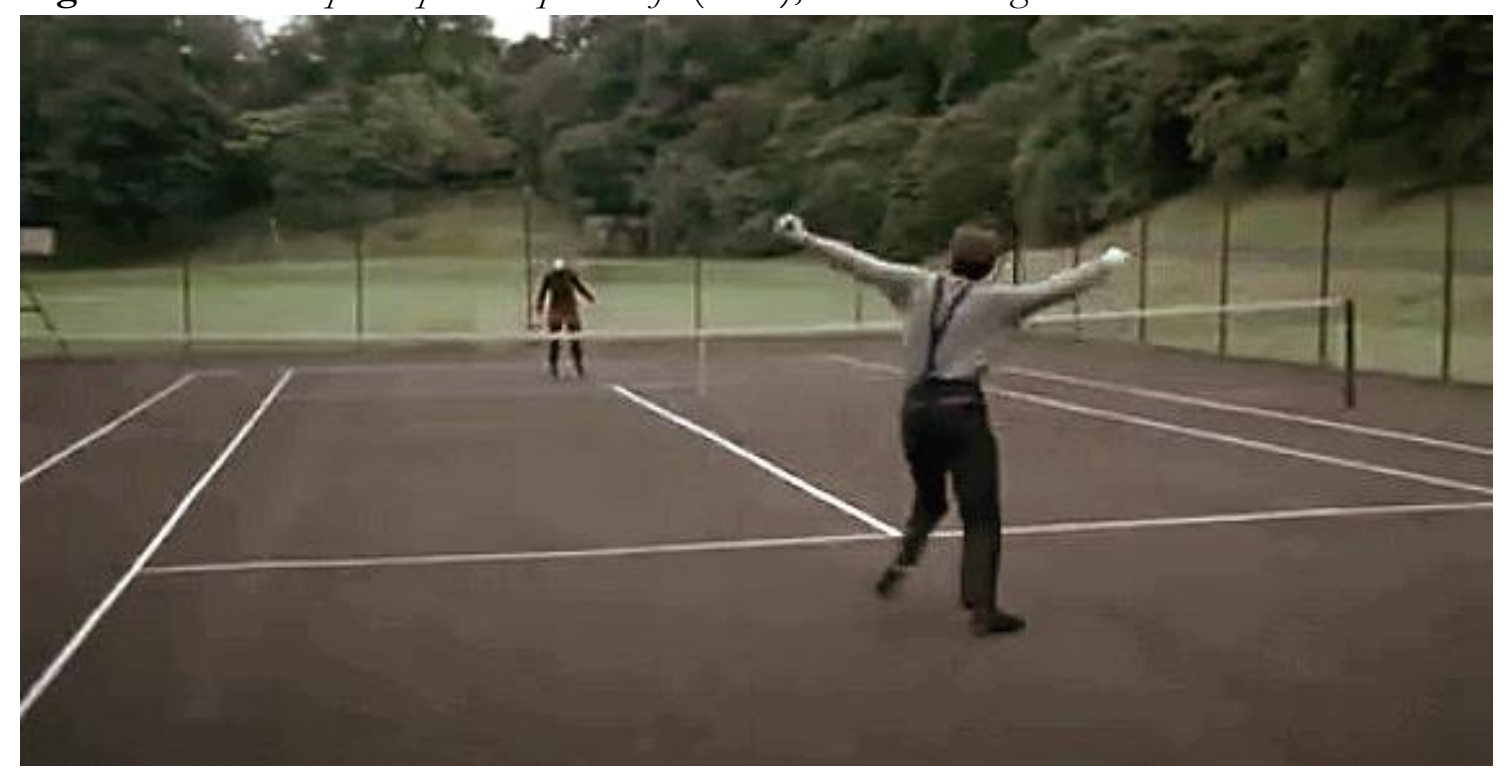

Fonte: (ANTONIONI, 1966).

A trama do filme de Antonioni também se ambienta na cidade de Londres, de onde o protagonista pensa em sair, alegando que a cidade não lhe faria bem. A casualidade com que o fotógrafo acaba descobrindo o crime, a ampliação das fotografias e toda a busca obstinada e infrutífera para desvendar a identidade da vítima funcionam, no filme, como novas metáforas sobre a invisibilidade do mistério, a ausência da busca por uma explicação possível ou ao menos razoável para certos acontecimentos da vida. O tema nos permitiria refletir sobre a existência dos mistérios escondidos nos lugares mais improváveis. Já o parque dos mímicos - a encenação mimética de um jogo imaginário de tênis - surge como grande alegoria da humanidade, em que as angústias, tragédias e problemas pessoais são, vez ou outra, capturados, não passando, porém, de preocupações fugazes. Nesse sentido, o filme também poderia ser visto como uma crítica ao perigoso encadeamento causal dos fatos, à racionalização do mistério e à normatização da vida.

Em Crimes e Pecados (ALLEN, 1989), Woody Allen já havia tensionado algumas dessas questões morais manifestas em "Crime e Castigo", mesclando-as com histórias paralelas e com outras remissões, fazendo lembrar o menos conhecido Monsieur Verdoux (1947), de Charlie Chaplin - especialmente o tom policial, embora aqui o personagem se aproxime mais do perfil dostoievskiano, ao casar e assassinar as mulheres para roubar dinheiro e manter sua família -, e Morangos Silvestres (1957), de Ingmar Bergman, especialmente na reflexão sobre a passagem do tempo e sobre o conjunto das escolhas que fazem do ser humano aquilo que ele se tornou, sobretudo aquelas tomadas em momentos de crise, raiva, medo ou em momentos irracionais ou patológicos de paixão:

Mas definimos a nós mesmos pelas escolhas que fizemos. Na verdade, somos feitos da soma total das nossas escolhas. Tudo se dá de maneira tão imprevisível, tão injusta, que a felicidade humana não parece ter sido incluída no projeto da Criação (ALLEN, 1989).

O filme seria uma resposta menos lírica à Hannah e Suas Irmãs (1986), ao mesmo tempo que constrói uma linha tenuemente cômica e cínica que utiliza a metáfora da visão 
para estabelecer uma reflexão mais profunda sobre a cegueira e a miopia da vida dos seres humanos e na sua relação com Deus. Nesse sentido, acaba se afastando do aspecto da tensão trágica que presenciamos em Match Point, ainda que os temas do acaso, do feminicídio, da culpa e da crise de consciência dos personagens masculinos sejam também o ponto central do enredo. O personagem principal, Judah Rosenthal, é um médico rico e bem-sucedido, uma figura exemplar de uma família tradicional, acima de qualquer suspeita, que decide se livrar de sua amante, Dolores, quando esta resolve confrontá-lo e revelar o caso à sua esposa. Ele decide, a partir de uma conversa com seu irmão, que a melhor solução é pagar para alguém assassiná-la, simulando um assalto em seu apartamento, assim como presenciamos em Match Point. Após o crime, ele é tomado por uma crise momentânea de consciência.

O filme explora um jogo interessante entre a especialidade médica do protagonista, um oftalmologista, e o fato dele próprio ter se tornado o mandante e a testemunha ocular da morte de sua amante. A simbologia do olho é notória desde o início do filme, na cena de abertura em que o protagonista faz um discurso, na festa em sua homenagem, relembrando os preceitos judaico-religiosos e a frase que seu pai lhe repetia durante a infância: "Nada escapa aos olhos de Deus". Também na cena em que ele presencia o corpo da amante assassinada: seus olhos estão abertos e o filme traz um flashback da personagem contando ao amante que a mãe dizia que os olhos são o espelho da alma. Há ainda uma outra cena importante, em que Judah vai ao encontro do rabino que era seu paciente e sofria de um processo degenerativo de perda da visão, outra sutil metáfora que parece indicar que se os olhos são mesmo o espelho da alma, esse espelho seria inútil aos espiritualmente cegos. Quando o médico se confidencia ao rabino, ele questiona o aspecto moral do ato criminoso dizendo o seguinte: "Eu não poderia viver sem a crença em um sistema moral com um verdadeiro significado e perdão, regido por um poder superior. Senão, não há base de conduta. E sei que há uma centelha dessa crença em você também". E completa: “Acha que Deus não verá?". A esta questão, o médico responde: "Deus é um luxo que não posso me permitir" (ALLEN, 1989). Enquanto o rabino, um homem de fé e de moral inabalável, fica completamente cego ao final do filme, não conseguindo enxergar o casamento da filha, o médico oftalmologista se livra da culpa e de qualquer ato de punição pelo assassinato planejado e executado, levantando a dúvida final sobre a existência ou não de um ser superior capaz de punir os criminosos e pecadores e premiar os moralmente os virtuosos.

\section{Considerações finais}

A filmografia de Woody Allen atravessa os temas da sorte, do destino e do acaso, sempre relacionados a uma reflexão sobre o sentido da vida e sobre os limites éticos entre as ações humanas e as providências sobrenaturais, numa oscilação entre o trágico e o cômico. Especialmente em filmes como Match Point, o gênero trágico é reafirmado pela presença de elementos que teriam como finalidade a purgação de emoções como a compaixão e o terror, assim como expressava Aristóteles em sua "Poética" (1959). O diretor parece encontrar no trágico a formulação estética capaz de criar uma identificação entre espectadores e as sensações vividas pelas personagens, justamente o que o filósofo grego definiu como catarse. Nossa identificação com protagonistas como Chris também se enquadraria na caracterização sobre sua impureza e falta de caráter, gerando uma empatia por parte do público no 
reconhecimento de falhas pertinentes à conduta do ser humano comum. Nas tragédias gregas, o personagem central costuma ser o corifeu, cujo líder do coro reconhece suas falhas e confessa seu erro na busca pela redenção. Para a finalização do sistema trágico, na perspectiva aristotélica, ainda seria necessário haver a catástrofe, mais amplamente conhecida como o final terrível próprio da tragédia.

No entanto, embora haja, na cinematografia de Allen, diálogos com o conceito clássico de destino, observamos igualmente uma subversão radical da lógica trágica, especialmente quando pensamos no desfecho de personagens como Nola, em Match Point, e em Dolores, em Crimes e Pecados, já que não são elas as protagonistas das ações narrativas, embora sejam seus corpos aqueles sacrificados para que a manutenção das peripécias aconteça nas tramas. Quando pensamos na forma clássica dos grandes heróis trágicos, aqueles que lutam contra as previsões oraculares, os caprichos dos deuses e a força do destino, personagens como Chris Wilton e Judah Rosenthal ganham, ao contrário, uma dimensão anti-heroica, justamente porque suas ações não os fazem agonizar em suas existências. Embora confessem intimamente seus próprios pecados e tenham a dimensão da consciência atormentada - o que se confirma na melancolia do caráter de Chris, por exemplo -, esses personagens nunca buscam ou alcançam qualquer possibilidade de redenção: o que existe é a certeza sobre a ausência de justiça e punição para seres como eles. Dessa forma, a catástrofe ganha outras dimensões.

A perspectiva terapêutica de Wittgenstein - ao percorrer os seus jogos sempre imprevisíveis de linguagem e ao se afastar da tentativa de estabelecer entre eles conexões causais que possam, porventura, costurar com um sentido único, definitivo, determinado e determinístico os problemas que submete à investigação - acaba por reconhecer que as regras dos jogos de linguagem que se jogam em quaisquer formas de vida nunca são prescritivas e que a tragédia da linguagem se daria a partir da constatação de sua radical incapacidade de descrever o que realmente importa: o mistério.

\section{Referências}

ADORNO, Theodor. W. Dialética Negativa. Trad. José Maria Rispalda. Revisor Jesús Aguirre. Madrid: Taurus, 1975.

Mínima Moralia: reflexões a partir da vida danificada. 2. ed. São Paulo: Ática, 1993.

Educação após Auschwitz. In: Educação e Emancipação. Trad. Wolfgang Leo Maar. Rio de Janeiro: Paz e Terra, 1995.

. Teoria estética. Trad. Artur Morão. Lisboa: Ed. 70, 2008.

ADORNO, Theodor. W.; HORKHEIMER, Max. Dialética do esclarecimento.

Tradução de Guido Antonio de Almeida. Rio de Janeiro: Jorge Zahar, 1985. 
ALLEN, Woody. Noivo neurótico, noiva nervosa. Direção: Woody Allen. Produção: Fred T. Gallo. Intérpretes: Woody Allen, Diane Keaton, Tony Roberts. Roteiro: Woody Allen e Marshall Brickman. Estados Unidos. (93 min.), son., color., 35 mm, 1977.

. Manhattan. Direção: Woody Allen. Produção: Charles H. Joffe. Intérpretes: Woody Allen, Diane Keaton, Michael Murphy, Mariel Hemingway, Meryl Streep, Anne Byrne e outros. Roteiro: Woody Allen e Marshall Brickman. Los Angeles: United Artists (96 min.), son., color., $35 \mathrm{~mm}, 1979$.

Hannah e suas irmãs. Direção: Woody Allen. Produção: Intérpretes: Barbara Hershey, Carrie Fisher, Michael Caine, Mia Farrow, Dianne Wiest, Maureen, O'Sullivan, Max von Sydow. Roteiro: Woody Allen. Estados Unidos (103 min.), son., color., 1986.

Crimes e Pecados. Direção: Woody Allen. Produção: Charles H. Joffe e Jack Rollins. Intérpretes: Martin Landau; Woody Allen; Bill Bernstein e outros. Roteiro: Woody Allen. Los Angeles: Jack Rollins \& Charles H. Joffe Productions (104 min.), son., color., $35 \mathrm{~mm}, 1989$.

Escorpião de Jade. Direção: Woody Allen. Produção: Letty Aronson, Walter E. Rollins. Intérpretes: Woody Allen, Dan Aykroyd, Helen Hunt, Brian Markinson, Wallace Shawn, David Ogden Stiers, Charlize Theron, Elizabeth Berkley. Estados Unidos/Alemanha. Califórnia: Gravier Productions, DreamWorks SKG. (110 min.), son., color, 2001.

Match Point. Direção: Woody Allen. Produção: Stephen Tenenbaum.

Intérpretes: Scarlett Johansson; Jonathan Rhys Meyers; Emily Mortimer e outros. Roteiro: Woody Allen. Londres: BBC Films; Thema Production; Jada Productions; Kudu Films. (124 min.), son., color., 35 mm, 2005.

. Scoop - O Grande Furo. Direção: Woody Allen. Produção: Letty Aronson, Nicky Kentish Barnes, Helen Robin, Stephen Tenebaum, Gareth Wiley, Charles H. Joffe e Jack Rollins. Intérpretes: Woody Allen, Scarlett Johansson, Hugh Jackman, Ian McShane, Charles Dance, Romola Garai. Estados Unidos (96 min.), son., color., 2006.

Tudo pode dar certo. Direção: Woody Allen. Produção: Letty Aronson, Stephen Tenenbaum. Intérpretes: Larry David, Evan Rachel Wood, Henry Cavill, Patricia Clarkson, Ed Begley, Jr., Michael McKean. Roteiro: Woody Allen. Estados Unidos (92 min.), son., color., 2009.

Meia-noite em Paris. Direção: Woody Allen. Produção: Javier Méndez.

Intérpretes: Owen Wilson; Rachel McAdams; Kathy Bates e outros. Roteiro: Woody Allen. Barcelona: Mediapro; Versátil Cinema; Gravier Productions; Pontchartrain Productions; TV3, (94 min.), son., color., 35 mm, 2011. 
Magia ao Luar. Direção: Woody Allen. Produção: Ronald L. Chez. Intérpretes: Colin Firth; Emma Stone; Marcia Gay Harden e outros. Roteiro: Woody Allen. Londres: Dippermouth Productions (97 min.), son., color., 35 mm, 2014.

Homem Irracional. Direção: Woody Allen. Produção: Letty Aronson, Stephen Tenenbaum, Edward Walson. Intérpretes: Jamie Blackley, Emma Stone, Joaquin Phoenix, Parker Posey. Roteiro: Woody Allen. Estados Unidos. (96 min.), son., color., 2015.

Café Society. Direção: Woody Allen. Produção: Letty Aronson, Stephen Tenenbaum e Edward Walson. Intérpretes: Jesse Eisenberg, Kristen Stewart, Steve Carell, Parker Posey, Blake Lively, Corey Stoll e outros. Roteiro: Woody Allen. Los Angeles: Alisa Lepselter. Gravier Productions, Perdido Productions e FilmNation Entertainment (96 min.), son., color., $35 \mathrm{~mm}, 2016$.

ARISTÓTELES. Poética. Tradução de Antônio Carvalho. São Paulo: Difusão Européia do Livro, 1959.

BAKHTIN, Mikhail. Problemas da poética de Dostoiévski. Trad. Paulo Bezerra. 4. ed. Rio de Janeiro: Forense Universitária, 2008.

BAPTISTA FILHO, Zito. A Ópera. 4. ed. Rio de Janeiro: Nova Fronteira, 1987.

BERGMAN, Ingmar. Morangos Silvestres. Direção: Ingmar Bergman. Produção: Intérpretes: Victor Sjöström, Bibi Andersson, Ingrid Thulin. Roteiro: Ingmar Bergman. Suécia (91 min.), son, p\&b, 1957.

. O sétimo selo. Direção: Ingmar Bergman. Produção: Allan Ekelung. Intérpretes: Max Von Sydow, Gunnar Björnstrand; Bengt Ekerot, Nils Poppe e outros. Roteiro: Ingmar Bergman. Suécia (96 min.), son., p\&b., 35 mm, 1957.

CHAPLIN, Charlie. Monsieur Verdoux. Direção: Charlie Chaplin. Elenco: Charles Chaplin; Mady Corell. Roteiro: Charles Chaplin e Orson Welles (ideia). Reino Unido (124 min.), son., p\&b, 1947.

DOSTOIÉVSKI, Fiódor. Crime e Castigo. Trad. de Paulo Bezerra. 3. ed. São Paulo: Editora 34, 2001.

. Os demônios. Trad. de Paulo Bezerra. São Paulo: Editora 34, 2004.

Memórias do subsolo. Trad. Boris Schnaiderman. 6. ed. São Paulo: Editora 34, 2009.

Os Irmãos Karamázov. Trad. de Paulo Bezerra. 3. ed. São Paulo: Ed. 34, 2012.

FREUD, Sigmund. O mal-estar na cultura. Porto Alegre: L\&PM, 2010. 
. Dostoiévski e o parricídio. In: FREUD, S. Inibição, sintoma e angústia: o futuro de uma ilusão e outros textos. Trad. Paulo César de Souza. São Paulo: Companhia das Letras, 2014. p. 275- 295.

HORKHEIMER, Max. O Eclipse da razão. São Paulo: Centauro, 2002.

MIGUEL, Fernanda Valim C. A hora presente: encenando a dor e o silêncio em A Hora da Estrela. Fólio - Revista de Letras, [S. 1.], v. 9, n. 2, fev.2018, p. 37-59. Disponível em: < http://periodicos2.uesb.br/index.php/folio/article/view/2789>. Acesso em: 8 out. 2020.

NIETZSCHE, Friedrich. Fragmentos Póstumos (1885-1889). Volumen IV. Madri: Tecnos, 2008.

SÓfOCLES. A Trilogia Tebana. Édipo Rei, Édipo em Colono, Antígona. A Tragédia Grega. v. 1. Trad. de Mário da Gama Kury. Rio de Janeiro : Zahar, 1990.

TRUFFAUT, François. Woody Allen, o pessimista alegre. In: TRUFFAUT, F. O prazer dos olhos: escritos sobre cinema. Trad. André Telles. Rio de Janeiro: Jorge Zahar Editor, 2005.

WITTGENSTEIN, Ludwig. Investigações filosóficas. Trad. José Carlos Bruni. São Paulo: Abril Cultural, 1979. (Os Pensadores, XLVI).

Cultura e valor. Trad. Jorge Mendes. Lisboa: Edições 70, 2000.

XAVIER, Ismail. O discurso cinematográfico: a opacidade e a transparência. São Paulo: Paz e Terra, 2008. 